\title{
What are the critical dimensions in Ghana's senior high school social studies curriculum? Under the lens of a critical global citizenship education framework
}

\author{
Simon Eten Angyagre* - UCL Institute of Education, UK \\ Albert Kojo Quainoo - University for Development Studies, Tamale, Ghana
}

\begin{abstract}
A review of school curricula approaches to citizenship formation in a sub-Saharan African education context reveals such practice is still largely focused on a traditional social studies approach. This approach to citizenship development may be limiting in terms of potential to foster students' civic competencies for addressing social injustice associated with the impacts of globalization that impinge on local realities. Drawing on a critical global citizenship education (GCE) framework and GCE core conceptual dimensions developed by UNESCO, this study assessed the critical dimensions of the social studies curriculum for secondary education in one sub-Saharan African country. Through interviews with teachers, focus groups with students and a review of the social studies teaching syllabus, the study revealed limitations in both content and the pedagogical approach to the delivery of Ghana's current social studies curriculum for senior high schools.
\end{abstract}

Keywords: global citizenship education, critical and global dimensions, globalization, colonialism, social studies, senior high schools, curriculum, Ghana

\section{Introduction}

The accelerated processes of globalization and the impacts these have on societies and economies around the world highlight the need for a global perspective to the delivery of education. This global perspective is particularly relevant in citizenship education given the fluidity that now characterize conceptions of citizenship, identity and culture, linked to increasing global mobility and the resultant intercultural contacts (Dei, 2004; Appiah, 2006; Rizvi, 2009). Global citizenship education (GCE) is an educational response to the increasingly globalizing world, and for meeting learners' civic and intercultural needs in relation to the processes and challenges of globalization towards fostering of a more just, equal and peaceful world (Oxfam, 2006). The relevance of global citizenship in the international education policy and programmes is echoed in Goal 4 of the United Nations Sustainable Development Goals (SDGs), which cites global citizenship along with Education for Sustainable Development as important targets of quality education, and instrumental for achieving sustainable development (UNESCO, 2016).

Research and school practice around GCE are, however, predominantly focused on the global North (Parmenter, 2011; Andreotti and De Souza, 2012) and have not yet been much applied to education systems in the global South (Jooste and Heleta, 
2017). The delivery of citizenship education in sub-Saharan African countries such as Ghana, Nigeria, Kenya and Tanzania is pursued mainly through a social studies approach characterized by a limited focus on national development issues (Sigauke, 2011; Mhlauli, 2012; Eten, 2015), deriving from factors that pertain to the peculiar sociocultural context and colonial histories of these countries.

In pre-colonial sub-Saharan African societies, the indigenous education delivered to local communities was community-driven and locally focused, and over time contributed to fostering citizenship education approaches that are culturally bound and focused on training individuals on specific societal values and norms. In explaining the nature of Africa's indigenous citizenship education in pre-colonial times, Mhlauli (2012: 106) has noted that, 'within the African traditional context, citizenship education was useful for inducting new members of society through the transmission of their cultural heritage to the young in order to develop a feeling of national pride in people.'

Furthermore, the form of citizenship education that was delivered to the citizenry of African countries under colonialism was not aimed at developing criticality in African subjects but was geared towards fostering an unquestioning allegiance of the colonized to the colonizer, and therefore did not have explicit critical focus (Shizha, 2014). Dei and Simmons (2016: 3) emphasize this by observing that, 'through a host of disciplinary discursive procedures, colonization produced a particular humanism, which avowed a certain form of moral citizenry' in colonized societies.

After gaining independence from colonial rule, African governments in the immediate postcolonial period sought to use citizenship education programmes to promote social cohesion and unity among the many political and ethnic divisions that resulted from the colonial project. One way this was pursued was in the establishment of the African Social Studies Programme (ASSP) in 1969 (EDC and CREDO, 1968), which promoted the teaching and learning of social studies as a school subject across the education systems of many African countries.

Following these historical antecedents in citizenship development in subSaharan African countries, curricular reforms undertaken in education systems of these countries have not yielded a significant focus on critical dimensions. Secondary education reforms have rather taken on a neoliberal turn with the marketization of school curricular under the pressures of global capital as a key defining feature (Dei, 2014; Maila and Awino, 2008). The central thesis of the article is that, for the youth in sub-Saharan Africa to effectively contribute to promoting democracy and good governance across the continent, it is important for competencies such as independent and critical thinking, civic courage and political awareness to be fostered in them through school subjects such as social studies.

The discussions conveyed in this article are aimed at contributing to the debate on citizenship education, drawing on a country-specific investigation into the extent to which Ghana's social studies curriculum relates to themes and pedagogies of GCE. The social significance of the study is that it demonstrates the need for a social studies curriculum that fosters students' civic, intercultural and critical competencies for contributing to sustainable development locally, regionally and globally. If GCE in the global North is situated within discourses of solidarity with the global South and aimed at promoting social justice and sustainable development (Oxfam, 1997), then it is imperative for the youth in the South to be given voice as part of this process, since they are positioned as direct subjects of globalization. This positionality enables them to communicate what it means to be youth and subjects of globalization, drawing on their local lived experiences. Such a process of empowerment holds the possibility of 
inspiring the youth into civic action in both local, regional and global development processes.

The introduction of the article is followed by a brief account of the research methodology that guided the study. There is an analysis of the political economy of the critical factors that have shaped schooling in Ghana and how this has contributed to shaping the country's civic and political landscape. This feeds into a broader discussion of the contribution of social movements in Ghana's political development and the role the study envisages for Ghanaian youth within civil society as critical global citizens. There is an outline of the constituent elements of the study's conceptual framework, detailing the framework within which the research questions were developed. Lastly, the findings of the study, as well as key conclusions and recommendations, are put forward in the final section of the article.

\section{The political economy of schooling in Ghana}

In Ghana's recent history, education reforms have largely been driven by neoliberal education agendas that aim at positioning the education system to respond to current trends and needs of globalization. Within such modernist education paradigms, school curricula goals increasingly focus on preparing students for the global economy (Kuyini, 2013), through which process prevailing economic and political status quos are perpetuated (Del Mar, 2012). Compared to private schooling, for example, Ghana's public school curricular is said to be of a lower quality, with 'hidden' curricula elements that foster in students attitudes of uniformity and conformity rather than independent and critical thinking (Addae-Mensah, 2000; Del Mar, 2012; Coe, 2005; Eten, 2015), a phenomenon that reverberates in education systems across many countries, where citizenship education programmes serve as tools for social control (Sigauke, 2011).

For Ghana's social studies curriculum, Del Mar (2012) has observed that social studies textbooks tend to denigrate the country's traditions and history, while glorifying its colonial past. The lack in criticality in social studies textbooks is evident in existing topics that focus less on critical discussions on civic engagement, political participation, Africa's history and culture as well as globalization processes. This situation has contributed to developing a sense of civic apathy in the educated youth and a lack of interest in discussions related to the country's history and cultural heritage. In regard to this disinterest, Hartman (2007: 71) has noted that Ghanaians have 'too many pressing concerns in everyday life to ruminate about the past'. There is rather a preoccupation with economic pursuits under economic and political conditions created by the political elite under a neoliberal national narrative of economic prosperity and progress (Del Mar, 2012).

Within such national narrative of economic prosperity, some have made the assessment that Ghana's much-trumpeted democratic stability and economic growth work mostly in the interest of the political elite and international capital, and much less so for the mass of Ghanaian citizenry (Abrahamsen, 2000; Langdon, 2010). Linked to the impacts of neoliberal globalization, the economic development agenda Ghana has pursued under the policy prescription of the World Bank and International Monetary Fund policy have not resulted in desired economic development (Ninsin, 2007), as a result of which, there has been growing sense of disillusionment, leading to civil society mobilization across different political and social divides to challenge the quality of governments' engagements with these Bretton Woods institutions. 
The role this article envisages for Ghana's youth as critical global citizens is situated within the civic and political spaces within which social and political movements have acted to delegitimize unpopular government policies and programmes. In Ghana's recent political history and democratization efforts, social and political movements have been instrumental in resisting unpopular neoliberal policy regimes (Langdon, 2010). However, this resistance has mainly been championed by civil society organizations and the country's intelligentsia group in spaces of institutions of higher learning, with little involvement of the mass of Ghanaian citizenry. The call for a critical global pedagogy to be introduced into Ghana's social studies curriculum derives from its potential to empower the youth to engage individually and collectively in civic and political action.

\section{Theoretical orientation and methodological choices}

This section presents an overview of the methodological choices and theoretical orientations of the study, providing a description of research participants and site and outlines the theoretical paradigms within which the study's conceptual framework is developed.

\section{Research participants}

As an exploratory qualitative study, it drew mainly from the views and experiences of teachers and students across five senior high schools in the Tamale Metropolis of the northern region of Ghana. Using purposive sampling, a total of 20 social studies teachers and 50 social studies students participated in the study. Teachers were engaged through in-depth interviews and students participated in focus groups. Five lesson observation sessions were also conducted, with a session in each school. The teaching syllabus for social studies was also reviewed through document analysis.

Although a qualitative study of this kind mainly draws on analytical generalizability to establish the validity of findings (Steinberg, 2015; Smith, 2018), it is worth noting that the study was limited to social studies teachers and students in the Tamale Metropolis of the northern region of Ghana. As such further research may be required in other regions of the country to gain a broader understanding of the views and experiences of teachers and students on global citizenship. Teachers' and students' views and experiences on global citizenship may differ from one geographical region to the other, linked to different levels of socio-economic development, different ethnic composition and character (multi-ethnic or otherwise) of the population, or exposure of teachers and students to topics related to global citizenship. However, in regard to the social studies teaching syllabus from which topics were selected for review, this is the teaching syllabus for social studies for all senior high schools across the country.

\section{Study conceptual framework}

In developing a framework for this study, Andreotti's (2006) critical GCE framework and UNESCO (2015) GCE core conceptual dimensions provided some guiding principles. These principles aided in the development of a set of specific critical GCE teaching objectives, which in turn informed the development of the conceptual framework for the study. To that extent, the principles guided the formulation of the study research questions. 
Andreotti's (2006) critical GCE framework was essential for the study in terms of the critical perspectives it brings to the discourse of GCE. The strength of this critical perspective lies in its ethical and reflective approach to promoting global citizenship, drawing from postcolonial theory and critical pedagogy. Given that Ghana's education system is situated within a broader postcolonial context, a critical approach was deemed instrumental in examining the impact of historical colonialism and current processes of neoliberal globalization on Ghana's education generally and the content and pedagogy of Ghana's social studies curriculum (Andreotti and de Souza, 2012). Specifically, critical pedagogy as a learner-centred approach to teaching holds the potential of empowering students to become 'critical thinkers and transformative actors' (Giroux, 1987: 180). Though Andreotti's critical GCE framework was originally conceptualized to address understanding and practice of global citizenship in the context of Europe and North America, this study adapts the critical elements in the framework for assessing Ghana's social studies curriculum. As such, the following critical perspectives on GCE were drawn from Andreotti's (2006) critical GCE framework for the study:

- The focal problem of GCE is inequality and injustice in society.

- The problem GCE seeks to address is related to complex global structures and systems, cultural assumptions as well as power relations that create and maintain exploitation and enforced disempowerment.

- The basis for caring in discourses of GCE is related to justice and complicity in harm, responsibility and accountability to the other.

- The principles of change that underpin GCE are reflexivity, dialogue, contingency, and ethical relation to difference (radical alterity).

- The goal of GCE is to empower individuals:

- to reflect critically on the legacies and processes of their cultures and contexts,

0 to imagine different futures, and

O to take responsibility for their decisions and actions.

- The potential benefit of GCE is in fostering independent and critical thinking and more informed, responsible and ethical action in individuals.

UNESCO (2014) conceptualizes GCE as a framing paradigm for citizenship education towards developing in learners the knowledge, skills, values and attitudes needed for building a peaceful, secure, inclusive and sustainable world. Along a civic, social and political socialization function of education, UNESCO has developed three GCE core conceptual dimensions of learning within which certain competencies, skills and values can be pursued (Table 1). These three GCE core conceptual dimensions of learning aided the development of specific GCE teaching goals for the study's conceptual framework.

\section{Table 1: UNESCO GCE core conceptual dimensions of learning}

1 Cognitive: To acquire knowledge, understanding and critical thinking about global, regional, national and local issues and the interconnectedness and interdependency of different countries and populations

2 Socio-emotional: To have a sense of belonging to common humanity, sharing values and responsibilities, empathy, solidarity and respect for difference and diversity

3 Behavioural: To act effectively and responsibly at local, national and global levels for a more peaceful and sustainable world

Source: UNESCO, 2015 
Drawing from UNESCO's GCE core conceptual dimensions and Andreotti's critical GCE framework, Table 2 is a representation of teaching goals for critical GCE. These teaching goals contribute to developing the conceptual framework of the study in assessing the teaching objectives, content and learning outcomes of Ghana's senior high school social studies curriculum.

\section{Table 2: Teaching objectives for critical GCE}

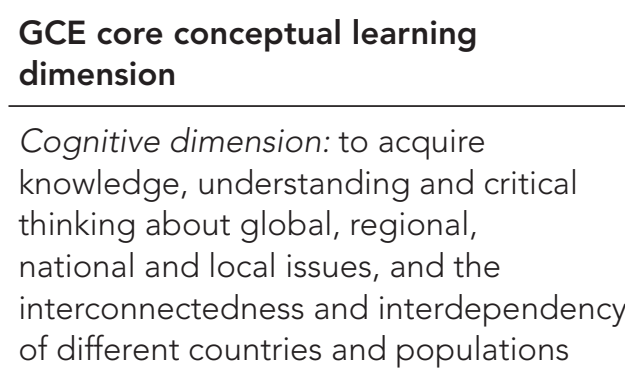

Socio-emotional dimension: to have a sense of belonging to common humanity, sharing values and responsibilities, empathy, solidarity and respect for difference and diversity

Behavioural dimension: to act effectively and responsibly at local, national and global levels for a more peaceful and sustainable world

\section{Teaching objectives}

Critical GCE should develop in students:

- independent and critical thinking about local/global issues

- understanding of complex global structures and systems

- understanding on how global systems create and maintain exploitation and enforced disempowerment

- understanding of the causes that underlie inequality and injustice in the world

Critical GCE should foster in students:

- a sense of belonging to global community

- a sense of empathy and solidarity

- respect for difference and diversity

- ability to imagine different futures

- reflexivity over one's own cultural context

Critical GCE should develop in students a willingness to:

- engage with global issues

- take action to change unjust and exploitative structures

- take action to change negative cultural assumptions and stereotypes about others

- engage in informed, responsible and ethical action

Source: Andreotti, 2006; UNESCO, 2015

The social studies syllabus spells out the problem description and general objectives for all topics, aimed at guiding teachers in the planning and delivery of social studies lessons, shown in Table 3. These problem descriptions, general objectives and content for selected topics in the social studies syllabus were assessed within the framework of the critical GCE teaching objectives developed in Table 2. The assessment aided in the development of broader questions which are then used to formulate specific research questions to guide reviews of the social studies teaching syllabus, classroom observation sessions, as well as interviews with teachers and students around content and methodology in social studies lessons. 


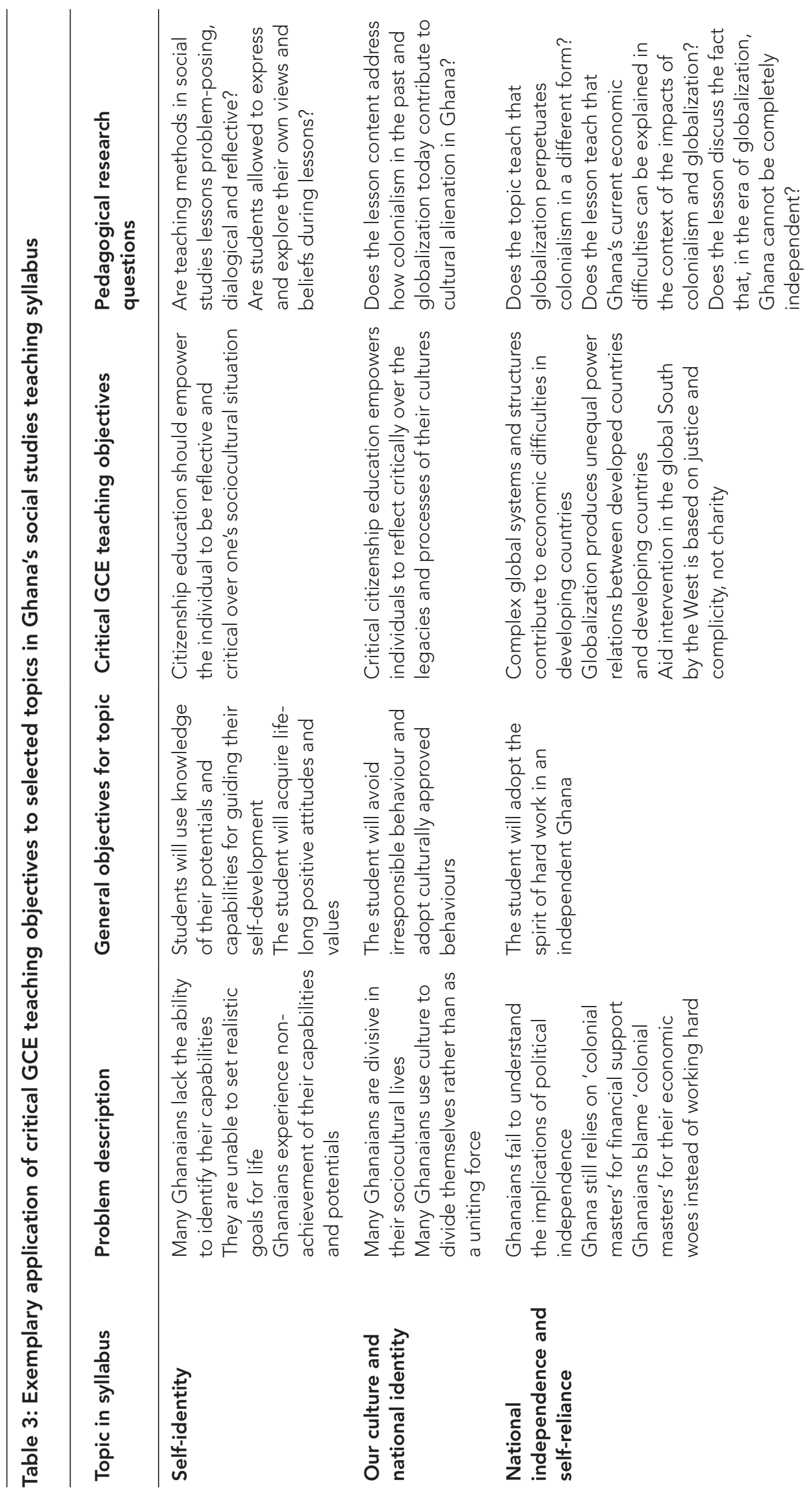




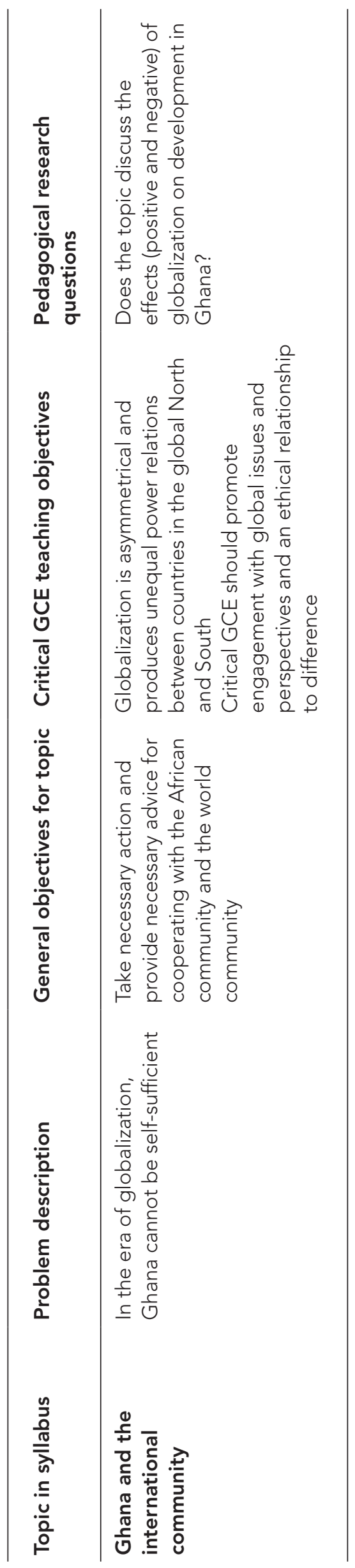




\section{Discussion of findings}

Following analysis of triangulated data from interviews, focus group discussions and document analysis, different themes were developed in line with the topics on global citizenship: globalizations, Africa's history and culture, as well as some pedagogical dimensions of Ghana's social studies curriculum. The findings of the study are presented and discussed along these themes.

\section{Teachers' and students' views on global citizenship}

Across all participating schools, most teachers and students in the study demonstrated a limited familiarity with the concept of global citizenship. However, in one of the few cases where a teacher reported he had heard of the term global citizenship, he elaborated that:

The first time I heard about global citizenship was when a friend of mine (who is the Regional Director of the National Commission for Civic Education in the Northern Region of Ghana) asked me what social studies teachers were doing to introduce to our students the concept of global citizenship. My reply to him was that, as social studies teachers, we were only responsible for teaching what was in the social studies syllabus and if the policy makers (Ministry of Education) decide that we should teach about global citizenship, we will teach it, if it is added to the syllabus. (Teacher 1)

This statement is significant in revealing the importance of curriculum and policy reform in any efforts to introduce dimensions of GCE into Ghana's social studies curriculum. This study was limited to the social studies curriculum in respect of teaching and learning practices at the school level and did not extend to investigating what education policy initiatives had been undertaken by Ghana's Ministry of Education to make the social studies curriculum globally relevant. Education policy in Ghana related to GCE is therefore an unexplored area of research that needs investigation.

The limited familiarity teachers and students demonstrated of the term global citizenship notwithstanding, they were able to offer some understanding of global citizenship based on their comprehension of the terms 'global' and 'citizenship'. In this regard, a teacher and a student defined a global citizen as:

Global citizenship has to do with relationships with other countries and one's depth of knowledge on global issues, and ability to interact with people of other countries. (Teacher 2)

A global citizen is someone who is able to interact with people of other nations and able to know their culture. (Student 2)

The dominant understanding demonstrated by teachers and students of global citizenship related more to a sense of being a citizen of the world, coupled with an interest and skill in interacting with people from different parts of the world. Along this understanding, the role of GCE was seen in developing the intercultural competencies of students for this purpose, with a key missing element being the social justice imperatives in GCE discourses.

It is worth highlighting that the views shared by teachers and students were based on their rudimentary understanding of the constitutive terms of 'global' and 'citizenship' rather than any systematic understanding they had acquired through 
study or training, given that most teachers and students reported a limited familiarity with the term global citizenship.

An important goal underpinning the teaching of critical GCE is active citizenship development (Ross et al., 2014). As such, the study sought to understand the extent to which Ghana's social studies curriculum was aimed at developing active citizenship. Teachers were asked to identify from three goals, the one that had a close association with Ghana's social studies curriculum. These three goals are derived from the theoretical traditions in social studies education developed by Barr et al. (1977) and Martorella (1996), which include: the development of good and obedient citizens; the development of critical and active citizens; the development of employable citizens.

Most teachers were of the view that the goal for teaching social studies is for developing good and obedient citizens. As to why this view was held, one of the teachers explained that:

There are topics in the social studies curriculum that we use to teach and encourage students to participate in community labour and to pay taxes to the state, but there are no topics that we use to teach students to be critical of government policies and projects. (Teacher 3 )

The dominant view held by teachers seems to reflect what the curriculum designers of Ghana's social studies curriculum envisaged as the goal for the teaching of the subject. This is evident in one of the stated aims for the teaching of the subject: 'The syllabus is designed to help students ... to become responsible citizens capable and willing to contribute to societal advancement' (CRDD, 2010: ii). Some teachers interpreted responsible citizenship as a middle ground between obedient citizenship and critical citizenship. These teachers saw responsible citizenship as citizenship that is submissive to authority, participates and contributes to community and national development, while at the same time being critical of the actions and inactions of public officials. Teachers further noted that, in social studies lessons, besides focusing on provisions in the teaching syllabus, they also negotiated the teaching and learning processes with their own discretion and experiences to ensure the process aimed at cultivating responsible citizens.

\section{Social studies curriculum provision on global issues}

One learning outcome associated with UNESCO's (2015) core GCE conceptual dimensions is knowledge of global governance systems and structures. In line with this, the study investigated how Ghana's social studies curriculum is related to global issues, given the accelerated processes of globalization and their impacts on Ghana's development. This was in regard to teachers' perceptions of the adequacy of provisions on global issues in the social studies syllabus, and how teachers connected their social studies lessons to discussions on global structures and systems. All social studies teachers in the study indicated there was no adequate provision on topics on global issues in the syllabus because there were few topics in the syllabus that connected specifically to globalization and generally on Ghana's relationship with other countries. These few topics were named as:

- national independence and self-reliance

- Ghana and the international community

- constitution, democracy and nation building.

In expressing a view on the limited provision of the social studies curriculum on global issues, Teacher 1 in an interview explained that: 
The senior high school social studies syllabus is structured to discuss national issues with only a few topics that focus on Ghana's relationship with the international community ... even in those cases where the international community is discussed, such discussions are limited to descriptions and not the impact of such relations.

For students, many of the lessons they studied in social studies were not directly related to global issues, but there were a few topics that discussed Ghana's relationship with the international community. In naming these few topics, students confirmed the topics listed by teachers. Furthermore, students noted that there were other subjects, besides social studies, from which they learned about global issues and Ghana's international relations. These subjects were named as economics, geography, history and government. These are elective subjects in Ghana's senior high school curriculum taken mostly by students who pursue the general arts programme, and not for students studying programmes such as general science and agriculture science. As a core subject, social studies is therefore the only examinable subject that provides opportunity for all students in senior high schools in Ghana to learn citizenship and civic issues (Quashigah, 2014), making it a significant entry point in any efforts to develop the global civic competencies of students.

\section{Social studies curriculum provision on Africa's culture and history}

An important focus in the study was on the impact of the colonial history on Ghana's socio-economic and cultural development. Teachers and students offered varied views on how themes on Africa's culture and history featured in social studies lessons and how Ghana's colonial history, in particular, impacts on its current development.

Most teachers in the study sample were of the view that the social studies syllabus did not contain adequate provisions on topics related to colonialism. In this regard, Teacher 6 expressed the concern that:

The social studies syllabus does not provide for discussing colonialism because there are no topics that directly talk about colonialism, and also mainly because of the lack of time. Even if a teacher is competent enough to introduce and discuss colonialism in his or her lessons with students, the limited time he or she has will not make that possible.

In responding to the same question, Teacher 2 noted that:

No, because colonialism is rarely discussed and only discussed if teacher decides to link it up to other topics, but there is no stand-alone topic on colonialism.

A different dimension to the inadequacy of the social studies curriculum on discussions on colonialism was brought to the fore by Teacher 8 who observed that:

Social studies does not adequately address issues of colonialism because the few topics which relate to colonialism (National independence and self-reliance) only focus on the processes that led to independence, but not on the impact of colonialism on the Ghanaian society.

A number of teachers also pointed out they were able to frame discussions during social studies lessons to highlight the impact of colonialism on Ghana's current development. However, such framing was done in mostly neutral terms, and focused less on the critical aspects. Discussions in lessons that mentioned colonialism were not 
usually focused on being critical of the colonial project, but mostly were driven at the level of historical narratives and descriptions.

On the part of students, many were of the view that, though they had not studied topics that allowed for a direct discussion of colonialism and its impact on the Ghanaian society in social studies lessons, teachers sometimes related their discussions on other topics to colonialism.

An important element in the discourse of critical GCE that the study also sought to uncover was students' appreciation of multiculturalism and diversity. The UNESCO GCE core conceptual dimensions identify understanding of identities and respect for diversity and difference as one important GCE learning outcome (UNESCO, 2015). Ghana is a diverse society in terms of its ethnic and religious composition (OwusuAnsah, 2014), and developing the values and skills in students to appreciate interculturalism promotes peaceful coexistence among the different ethnic groups. Students were asked how they viewed and interacted with their peers of different cultural and religious background in the classroom and outside of the school. Some comments made by students include, among others:

I try to learn from my friends of different cultural and religious background instead of stereotyping them. (Student 9)

Irrespective of our religious background in the classroom, we see each other as brothers and sisters and tolerate each other's views. (Student 11)

Coming from a different background gives us the opportunity to learn from each other's cultures and religions. (Student 4)

\section{Critical elements in social studies topics}

The study reviewed a number of social studies topics in an attempt to investigate their critical elements. For the purposes of demonstration, analysis done on one topic is discussed in this paper, leadership and followership, which has particular relevance within the conceptions of developing students' agency in critical GCE (Andreotti, 2006). The syllabus problem statement is framed around poor conception of leadership and followership among Ghanaians. What is articulated characterizes the poor conception of leadership as due to leadership focusing on the acquisition of wealth, while followership among Ghanaians is expressed in attitudes of 'sycophancy' and 'bootlicking'. This problem statement captures some of the root causes of corruption and resource mismanagement in Ghana. However, in the content prescribed in the syllabus for discussing the topic, the recommended qualities of leaders and followers are far from qualities for transformational leadership and followership (Figure 1).

A close review of the recommended qualities of a follower in Figure 1 reveals that these qualities do not fall within qualities that promote critical followership. As discussed by Blackmore (2016), any teaching and learning experience founded on critical pedagogy should develop competencies, and readiness to engage and dialogue with the 'other' over difference. This is discussed in the second dimension (dialogue) of the critical GCE framework developed by Blackmore (2016). In the political sphere, dialogue or engagement over difference could be expressed in the form of civic engagement with political leaders to demand accountability and good governance. However, it can be said that not many of the recommended qualities for a follower in the syllabus resonate with civic competencies for engaging 


\begin{tabular}{|c|c|c|c|c|c|}
\hline UNIT & & SPECIFIC OBJECTIVES & \multicolumn{3}{|c|}{ CONTENT } \\
\hline UNIT 1 & The st & dents will be able to: & & & \\
\hline $\begin{array}{l}\text { LEADERSHIP AND } \\
\text { FOLLOWERSHIP } \\
\text { The Problem }\end{array}$ & 2.2 .1 & $\begin{array}{l}\text { state what leadership and } \\
\text { followers mean. }\end{array}$ & \multicolumn{3}{|c|}{$\begin{array}{l}\text { Leadership can be defined as having the authority to } \\
\text { guide others towards the attainment of set goals. }\end{array}$} \\
\hline $\begin{array}{l}\text { Many Ghanaians } \\
\text { seem to have poor } \\
\text { conception of } \\
\text { 'leadership' as }\end{array}$ & & & \multicolumn{3}{|c|}{$\begin{array}{l}\text { Followership on the other hand is the willingness to } \\
\text { support a leader in attaining common aspirations. } \\
\text { There is therefore a reciprocal relationship between } \\
\text { leadership and followership. }\end{array}$} \\
\hline $\begin{array}{l}\text { acquisition of } \\
\text { wealth while }\end{array}$ & 2.2 .2 & $\begin{array}{l}\text { examine the qualities of a } \\
\text { leader and a follower. }\end{array}$ & \multicolumn{3}{|c|}{ Qualities of a leader: } \\
\hline $\begin{array}{l}\text { followership is } \\
\text { made synonymous } \\
\text { with 'sycophancy' }\end{array}$ & & & $\begin{array}{l}\text { - humility } \\
\text { - tolerance }\end{array}$ & $\begin{array}{l}\text { - loyalty } \\
\text { - honesty }\end{array}$ & - vision \\
\hline and 'boot licking'. & & & \multicolumn{3}{|c|}{ Qualities of a follower: } \\
\hline $\begin{array}{l}\text { Such wrong } \\
\text { notions have } \\
\text { adversely affected } \\
\text { the socio- } \\
\text { economic } \\
\text { development of } \\
\text { the nation. }\end{array}$ & & & $\begin{array}{l}\text { - humility } \\
\text { - loyalty }\end{array}$ & $\begin{array}{l}\text {-cooperation } \\
\text { - sense of team } \\
\text { work }\end{array}$ & - dedication \\
\hline
\end{tabular}

Figure 1: Qualities of leaders and followers in the senior high school social studies syllabus

Source: CRDD, 2010

with difference. Most of the qualities (humility, loyalty, cooperation, dedication and sense of team work) outlined in the syllabus in some sense relate more to promoting 'sycophancy' and 'boot-licking' than to promoting civic engagement. Citizenship education that aims at promoting responsible followership among Ghanaians should rather focus more on promoting 'civic empowerment and civic courage' (Kickbusch, 1987: 176), and less on qualities such as 'humility' and 'loyalty'. The preceding discussions sought to highlight the limitations in the senior high school social studies syllabus in relation to critical dimensions, as conceptualized in critical GCE.

\section{Teaching methodology}

Central to any approach of teaching founded on critical theories of education is the use of the dialogic method of teaching, as expounded in Paulo Freire's (1970) Pedagogy of the Oppressed. The dialogic approach to teaching is preferred to the 'banking' approach because it puts students at the centre of the classroom experience, allowing for the exploration of their understanding and views on topics through participatory teaching practices, and in the process developing students' sense of agency and autonomy in solving problems. Pedagogies of active and collaborative teaching and learning are particularly well-suited in social studies lessons because of their inherent potential to develop students' civic competencies and skills (Plantan, 2004).

The majority of teachers indicated the use of the discussion method of teaching as opposed to the lecture method. This was confirmed by the views of students on the methodologies their teachers used in social studies lessons. Relating the responses of both teachers and students, the following were named as teaching strategies mostly used in social studies lessons by teachers:

- putting students in groups and giving them projects to accomplish

- asking and distributing questions equitably across the class

- using the discussion method of teaching 
- teachers putting students in groups to brainstorm given topics and report back to class.

Democratic teaching practices in a classroom setting have been found to be effective in instilling into students values such as tolerance, respect, diversity, inclusion and solidarity for active global citizenship (Fricke et al., 2015). One of the teaching strategies teachers can use to foster these democratic values is creating space for students to critique and assess their (teachers') views and lessons. Though the majority of teachers indicated they were tolerant of this practice, a few teachers noted they disallowed this practice in their lessons for good reasons. One of these good reasons was related by Teacher 1:

We have over the years noticed how significant it is for students to critique and assess how we teach them, but there is actually no time to do that. If you take your lesson that far, you are not going to be able to cover your syllabus.

\section{Conclusion and recommendations}

Given that global processes now constitute local realities, the implementation of GCE in educational systems in the global North has implications for education systems in sub-Saharan Africa. This underscores the need for education systems in African countries to begin to position school curricula in ways that respond to global relevance but situated within their ecological conditions and needs. One way to do this is appropriating GCE within conceptions of indigenous education expressed in African ontological and epistemological frameworks. Drawing on some examples, the Southern African concept of Ubuntu and the practical orientations around which pre-colonial African indigenous education was organized could help indigenize the concept of GCE in an African context.

This article has demonstrated that Ghana's current social studies curriculum has limited provisions on critical and global dimensions. The existing but limited provisions on content and pedagogy provide an entry point for reform towards making the social studies curriculum globally relevant. Such reform efforts must, however, take cognizance of existing challenges within the social studies curriculum and Ghana's broader education system. The study identified challenges related to the overloaded social studies curriculum and low quality in basic education, especially in rural regions of the country, which presents a potential challenge in terms of students' ability to discuss, comprehend and engage with the globally focused topics that are central to global citizenship discourses. The understanding of these challenges and the devising of strategies to address them will constitute an important starting point for a reform process.

The study recommends a critical global pedagogy for Ghana's social studies curriculum owing to the country's postcolonial context. This would include: a critical global pedagogy defined in terms of teaching goals and subject content with a local focus but global relevance; teaching methodologies informed by critical pedagogy; and learning undertaken within a framework of a critical engagement with the impacts of neoliberal globalization and historical colonialism on contemporary developments. The introduction of a critical global pedagogy should not necessarily involve the introduction of new stand-alone topics, as this may add to the already overloaded social studies curriculum. The subject-integration approach to introducing GCE 
dimensions into school curricular (UNESCO, 2015) is appropriate in dealing with the challenge of an overloaded curriculum.

Beyond this study, there is the need for research that investigates the schoolwide global dimensions of Ghana's education system. Potential areas of investigation are subject-specific areas besides social studies, school-wide curriculum norms, practices and ethos as well as education policy examined within existing efforts for making education in Ghana locally focused but globally relevant, especially within the framework of Goal 4 of the UN Sustainable Development Goals.

\section{Notes on the contributors}

Simon Eten Angyagre is a doctoral candidate at UCL Institute of Education, undertaking research on global citizenship and internationalization in higher education in Ghana. His current research interest is focused on global citizenship and internationalization in the context of African education systems.

Albert Kojo Quainoo is Professor of Biotechnology at the University for Development Studies in Tamale, Ghana and currently the Dean of the Faculty of Agriculture at the same university.

\section{References}

Abrahamsen, R. (2000) Disciplining Democracy: Development discourse and good governance in Africa. London: Zed Books.

Addae-Mensah, I. (2000) Education in Ghana: A tool for social mobility or social stratification? Accra: Ghana Academy of Arts and Sciences.

Andreotti, V. (2006) 'Soft versus critical global citizenship education'. Policy and Practice: A Development Education Review, 3, 40-51.

Andreotti, V. and De Souza, L.M.T.M. (2012) 'Introduction: (Towards) global citizenship education "otherwise"'. In Andreotti, V. and De Souza, L.M.T.M. (eds) Postcolonial Perspectives on Global Citizenship Education. New York: Routledge, 1-6.

Appiah, K.A. (2006) Cosmopolitanism: Ethics in a world of strangers. New York: Norton.

Barr, R.D., Barth, J.L. and Shermis, S.S. (1977) Defining the Social Studies. Arlington, VA: National Council for the Social Studies.

Blackmore, C. (2016) 'Towards a pedagogical framework for global citizenship education'. International Journal of Development Education and Global Learning, 8 (1), 39-56.

Coe, C. (2005) Dilemmas of Culture in African Schools: Youth, nationalism, and the transformation of knowledge. Chicago: University of Chicago Press.

CRDD (Curriculum Research and Development Division) (2010) Teaching Syllabus for Social Studies (SHS 1-3). Accra: Ministry of Education.

Dei, G.J.S. (2004) Schooling and Education in Africa: The case of Ghana. Trenton, NJ: Africa World Press.

Dei, G.J.S. (2014) 'Global education from an "indigenist" anti-colonial perspective'. Journal of Contemporary Issues in Education, 9 (2), 4-23.

Dei, G.J.S. and Simmons, M. (2016) 'Citizenship education and embodied ways of knowing: What can be learned from the voices of Ghanaian youth in schooling and education?'. Journal of Global Citizenship and Equity Education, 5 (1), 1-20.

Del Mar, D.P. (2012) 'A pragmatic tradition: The past in Ghanaian education'. Africa Today, $59(2), 22-38$.

EDC (Education Development Center) and CREDO (Centre for Curriculum Renewal and Educational Development Overseas) (1968) Report of a Conference of African Educators, EDC and CREDO on Social Studies Held at Mombasa, Kenya, 19th-30th August 1968. Newton, MA: Education Development Center. Online. https://files.eric.ed.gov/fulltext/ED042683.pdf (accessed 10 September 2019).

Eten, S. (2015) 'The prospects of development education in African countries: Building a critical mass of citizenry for civic engagement'. Policy and Practice: A Development Education Review, 20, 136-51. 
Freire, P. (1970) Pedagogy of the Oppressed. Trans. Ramos, M.B. New York: Continuum.

Fricke, H.-J., Gathercole, C. and Skinner, A. (2015) Monitoring Education for Global Citizenship: A contribution to debate. Brussels: DEEEP-CONCORD DARE Forum. Online. https://tinyurl.com/ y3zbluwn (accessed 10 September 2019).

Giroux, H.A. (1987) 'Citizenship, public philosophy, and the struggle for democracy'. Educational Theory, 37 (2), 103-20.

Hartman, S. (2007) Lose Your Mother: A journey along the Atlantic slave route. New York: Farrar, Straus and Giroux.

Jooste, N. and Heleta, S. (2017) 'Global citizenship versus globally competent graduates: A critical view from the South'. Journal of Studies in International Education, 21 (1), 39-51.

Kickbusch, K.W. (1987) 'Civic education and preservice educators: Extending the boundaries of discourse'. Theory and Research in Social Education, 15 (3), 173-88.

Kuyini, A.B. (2013) 'Ghana's education reform 2007: A realistic proposition or a crisis of vision?'. International Review of Education, 59 (2), 157-76.

Langdon, J. (2010) 'Strategies of social movements in Ghana: Questioning the dividends of democracy and/or being embedded in new topographies of power?'. Canadian Journal of Development Studies, 29 (3-4), 373-92.

Maila, M.W. and Awino, J.O. (2008) 'Reflections on quality education in African higher education'. Africa Education Review, 5 (2), 239-52.

Martorella, P.H. (1996) Teaching Social Studies in Middle and Secondary Schools. 2nd ed. Upper Saddle River, NJ: Merrill.

Mhlauli, M.B. (2012) 'The role of education on citizenship development in Africa'. British Journal of Arts and Social Sciences, 4 (1), 104-55.

Ninsin, K.A. (2007) 'Markets and liberal democracy'. In Boafo-Arthur, K. (ed.) Ghana: One decade of the liberal state. London: Zed Books, 86-105.

Owusu-Ansah, A.L. (2014) 'I am not prejudiced, or am I? Semantic strategies used by Ghanaian university students in the discourse of ethnic prejudice'. International Journal of Society, Culture and Language, 2 (1), 73-87.

Oxfam (1997) A Curriculum for Global Citizenship. Oxford: Oxfam.

Oxfam (2006) Education for Global Citizenship: A guide for schools. Oxford: Oxfam.

Oxley, L. and Morris, P. (2013) 'Global citizenship: A typology for distinguishing its multiple conceptions'. British Journal of Educational Studies, 61 (3), 301-25.

Parmenter, L. (2011) 'Power and Place in the discourse of Global Citizenship'. Globalisation, Societies and Education, 9 (3-4), 367-80.

Peters, M.A. (2010) 'Global citizenship education: Politics, problems and prospects'. Citizenship, Social and Economics Education, 9 (1), 43-7.

Plantan, F. (2004) The University as Site of Citizenship. The university as res publica. Strasbourg: Council of Europe Publishing, 83-128.

Quashigah, A.Y. (2014) 'Why teach social studies from a global and multicultural perspective?'. In Asabere-Ameyaw, A., Anamuah-Mensah, J., Dei, G.S. and Raheem, K. (eds) Indigenist African Development and Related Issues: Towards a transdisciplinary perspective. Rotterdam: Sense Publishers, 65-77.

Rizvi, F. (2009) 'Global mobility and the challenges of educational research and policy'. Yearbook of the National Society for the Study of Education, 108 (2), 268-89.

Ross, E.W., Mathison, S. and Vinson, K.D. (2014) 'Social studies curriculum and teaching in the era of standardization'. In Ross, E.W. (ed.) The Social Studies Curriculum: Purposes, problems, and possibilities. 4th ed. Albany: State University of New York Press, 25-49.

Shizha, E. (2014) 'Rethinking contemporary sub-Saharan African school knowledge: Restoring the indigenous African cultures'. International Journal for Cross-Disciplinary Subjects in Education, 4 (1), 1870-8.

Sigauke, A.T. (2011) 'Citizenship and citizenship education: A critical discourse analysis of the Zimbabwe Presidential Commission Report'. Education, Citizenship and Social Justice, $6(1), 69-86$.

Smith, B. (2018) 'Generalizability in qualitative research: Misunderstandings, opportunities and recommendations for the sport and exercise sciences'. Qualitative Research in Sport, Exercise and Health, 10 (1), 137-49.

Steinberg, P.F. (2015) 'Can we generalize from case studies?'. Global Environmental Politics, $15(3), 152-75$. 
UNESCO (United Nations Educational, Scientific and Cultural Organization) (2014) Global Citizenship Education: Preparing learners for the challenges of the twenty-first century. Paris: United Nations Educational, Scientific and Cultural Organization. Online. https://unesdoc. unesco.org/ark:/48223/pf0000227729 (accessed 10 September 2019).

UNESCO (United Nations Educational, Scientific and Cultural Organization) (2015) Global Citizenship Education: Topics and learning objectives. Paris: United Nations Educational, Scientific and Cultural Organization. Online. https://unesdoc.unesco.org/ark:/48223/ pf0000232993_eng (accessed 10 September 2019).

UNESCO (United Nations Educational, Scientific and Cultural Organization) (2016) Unpacking Sustainable Development Goal 4: Education 2030: Guide. Paris: United Nations Educational, Scientific and Cultural Organization. Online. https://unesdoc.unesco.org/ark:/48223/ pf0000246300_eng (accessed 10 September 2019). 